\title{
25
}

\section{Participatory sustainable waste management project in Brazil}

\author{
Crystal Tremblay and Sarah Amyot
}

\section{Context}

People who live off materials recovered from the waste stream exist in every corner of the world. However, these recyclers are among the most exploited and socially and economically excluded people. Recyclers face enormous stigmatization, discrimination and marginalization. This project was established to focus on participatory waste management as an opportunity to generate income and to improve the quality of life of informal recyclers (called catadores in Brazil), while promoting environmental sustainability and inclusive public policies on integrated waste management. The project recognizes the immense potential in the work of recyclers to improve environmental health, assist in the recovery of resources and, through capacity building and participatory processes, to empower recyclers to contribute to public policy, environmental and social change.

Project partners recognized that, when working individually, recyclers were forced to sell their product through middlemen who buy at very low prices and then resell to industry at a much higher rate. However, with support from the project, several groups of recyclers have established themselves as cooperatives. This has enabled them to pool their resources, avoiding middlemen, and to sell directly to industry. The results have been manifold: increasing the amount of recyclable material recovered from the waste stream; increasing wages for organized recyclers; increasing their bargaining power; and contributing to safer working conditions.

The main project objectives were:

- to structure, organize and strengthen cooperatives, associations and community groups involved in the recovery of resources from the solid waste stream, through supporting cooperatives, microcredit and the practice of solidarity economy;

- to support the inclusion of participants in the policymaking process/to affect policy change;

- to increase capacity of partner institutions to provide technical support and training to government and others in a wide range of areas, from business issues relating to recycling cooperatives to participatory methodologies. For example, the project aims to increase the capacity of the Faculty of 
Education (FEU) at the University of São Paulo (USP) to implement training programmes for government agents, leaders from the informal recycling sector and the wider community;

- to improve lives, skills, knowledge of recycler participants;

- to reduce waste/support sustainable waste solutions and to improve selective waste collection techniques;

- to increase collaboration among participants, other governmental and non-governmental institutions, other Brazilian cities and, on the international level, with groups on integrated solid waste management;

- to increase the capacity of the members of the Project Management Council to participate in local and international project management leading to new partnerships, and at least two new projects proposed by the Directing Committee on the thematic topics covered by the project.

\section{Organization/structure}

The project is governed by a Directing Committee made up of the original project partners (University of Victoria, University of São Paulo, Forum Recicla São Paulo, Rede Mulher de Educação) and a Project Management Council, responsible for operational and deliberative aspects (including yearly planning) of the project. The Project Management Council is made up of the members of the Directing Committee, representatives from six municipal governments and ten recycling cooperatives. This committee meets every three months. The project brings together university, community and government representatives in a participatory governance model. Supportive participatory management of the project is integral to the long-term success of the project and has helped it to be responsive to the needs and interests of the recycler groups.

The project is funded through a grant from the Canadian International Development Agency (CIDA), through the Association of University and Colleges Collaboration (AUCC) as a Tier II project under the University Partnership Collaboration and Development programme (2004-10). The project has also been able to leverage a number of smaller grants including one from the state oil company Petrobrás to finance a number of income generation projects.

\section{Activities}

The project is informed by participatory and action-oriented methodologies, employing a mixed-method approach, including interviews, surveys, focus groups, Photovoice, participatory video, community mapping and participatory observation (i.e., researchers participate in the work processes of the recyclers).Capacity building has also been an important element of the research approach. Activities take place with individual recyclers throughout the recycling associations and cooperatives. Specific activities have included participatory video workshops with recyclers; financial management workshops with cooperatives; capacity building for livelihood diversification through pilot projects, such as the collec- 
tion of organic (food) waste; and information technology skills workshops to help recyclers become more autonomous in the digital world and to use computers for co-op administration and collective commercialization.

\section{Outcomes}

The project has made material improvements in the lives of the recyclers: by helping them make infrastructure improvements and to buy new equipment for their work facilities; by improving their income levels through collective commercialization of recyclables; and by helping to strengthen their voice; and contributing to a more positive image of recyclers. Many participating recyclers have said that their participation in the project has made their lives a bit easier and increased their incomes. Many also speak about the impact of their participation on them personally, noting that the project has contributed to their empowerment and confidence. The direct impact in these areas can be difficult to measure; however, it is safe to say that the project is contributing to changing attitudes about recyclers and sustainable resource management, and, in turn, this contributes to positive environmental, economic and social impacts. As Jutta Gutberlet notes, 'Organized recycling programmes provide an opportunity to enhance public environmental awareness with the recyclers performing the role of environmental agents.'

There are a number of examples where the project has directly participated in policy discussions or has supported the participation of recyclers in policy discussions by providing valuable evidence-based research. The project is also now widely recognized and has been invited by other municipalities to advise on waste management strategies. In Ribeirão Pires, Santo André and Diadema, the project's Directing Committee and the field team arranged meetings and visits with representatives from the municipal governments. In São Paulo, the focus has been upon building relationships with some of the regional offices (sub-prefeituras). Seminars on participatory research methodologies were organized in partnership with municipal governments.

- In 2008 the project further enhanced a close working relationship with the complementary project (Rede ABC Gerando Renda) and the Regional Consortium of Municipalities in the $\mathrm{ABC}$ region of São Paulo. This relationship is key to achieve the project purpose when it comes to the implementation of participative management with the design of sustainable and equitable public policies on solid waste management.

- The project is significantly contributing to strengthening the Brazilian partner institutions and project beneficiaries, particularly professors and students from USP, members from Rede Mulher de Educação, Fórum Recicla São Paulo, and recycling cooperatives. Based on a 'learning by doing' approach, the project is helping its beneficiaries to apply organizational and management knowledge. Moreover, Brazilian and Canadian partners are systematically sharing knowledge in this and other areas, such as the organization of recyclers' groups, gender equity awareness and overall research activities related to waste management. 
- The project has broad national strategic importance as it fits into the Federal Government's Accelerating Growth Program (Programa de Aceleração do Crescimento), promoted by the current Brazilian president Luis Ignacio Lula da Silva, of which the main objectives are poverty relief and generation of new jobs.

- The project participants are strongly aware of the need to formulate and enforce policies to guarantee their participation and to improve the waste management process.

- The project has partnered with the MOTHERS pilot project (http://pswm. uvic.ca/en/initiatives/mothers.html), building bridges between the work done with recyclers in Brazil and the recyclers in Victoria. The MOTHERS project aims to empower and improve the quality of life of binners in Victoria by providing four specially designed bicycles and tent-trailers that will facilitate income generation opportunities and reduce the negative stereotypes that binners face.

- The project has resulted in the development of a global waste database data regarding all aspects of waste, such as generation, storage, recycling. Policy will be stored, analysed and disseminated. To support this outcome, the project has conducted digital inclusion workshops and training sessions to teach the recyclers computer skills.

- The project has resulted in the production and publication of a wide range of academic and popular publications, including the video Beyond Gramacho, which documents recyclers' struggles and the benefits of collective commercialization and co-op development.

- The project initiated a working capital fund managed by eight women in the metropolitan region of São Paulo. The fund provides small loans, allowing groups to survive until payment from industry arrives. This eliminates the need to sell to intermediaries and maintains income within the network. The initiative has also contributed to empowerment outcomes for the women involved.

- Speaking more generally about the project outcomes, the project has significantly contributed to the empowerment of the project participants who have taken on larger roles in regional and national organizations.

- The project has contributed to many positive legislative and policy changes by providing information and documentation to the recyclers' movement and by directly participating in policy discussions.

- The project has resulted in improvements in working conditions, wages and infrastructure for the recyclers.

- By working together in management committees and making collective decisions about project priorities and resources, the project has resulted in increased solidarity among participants.

- Lastly, as the global price for recyclables collapsed due to the economic crisis, the support provided by the project has enabled the participating recycling cooperatives to survive where others could not. 
The project has also made a number of contributions to theorizing the social and solidarity economies, areas of research that remain relatively undertheorized, while also contributing to the critical discourse on collective commercialization and microcredit. Further, the research has helped to expand the body of theory about community-based research and empowerment concepts. Lastly, researchers involved in the project are interested in contributing to the body of knowledge and practice about sustainable production and consumption. 